\title{
LUT
}

University

\section{Comprehensive performance measurement and management- Innovativeness and performance through reflective practice}

Ukko Juhani, Hildén Sanna, Saunila Minna, Tikkamäki Kati

This is a Post-print

version of a publication

published by Emerald Publishing

in Journal of Accounting and Organizational Change

DOI: $10.1108 / \mathrm{JAOC}-09-2015-0070$

Copyright of the original publication: (c) 2017 Emerald Publishing

Please cite the publication as follows:

Ukko, J., Hildén, S., Saunila, M., Tikkamäki, K. (2017). Comprehensive performance measurement and management-Innovativeness and performance through reflective practice. Journal of Accounting and Organizational Change, vol. 13, issue 3. pp. 425-448. DOI: 10.1108/ JAOC-09-2015-0070

This is a parallel published version of an original publication.

This version can differ from the original published article. 
Ukko, J., Hildén, S., Saunila, M. and Tikkamäki, K. (2017) Comprehensive performance measurement and management - Innovativeness and performance through reflective practice, Journal of Accounting and Organizational Change, 13 (3): 425-448.

\section{Comprehensive performance measurement and management—Innovativeness and performance through reflective practice}

\section{Structured Abstract:}

\section{Purpose}

The purpose of the study is to investigate how organizations can exploit performance management through reflective practice to foster innovativeness and performance.

\section{Design/methodology/approach}

A conceptual framework has been designed to link the studied concepts and to explicitly indicate current research gaps in the area. Moreover, we have conducted interventionist case studies to understand the interconnections between theory and practice.

\section{Findings}

This study showed that there are many possibilities with which to exploit performance management through reflective practice to foster innovativeness and performance. The study has three main implications. First, reflective practice can be learned and developed. Second, reflective practice is connected to innovativeness and performance. Third, performance management through PMSs can assist in targeting the reflective practice.

\section{Originality/value}

New forms of performance measurement and management are receiving increasingly amount of attention, because the traditional forms of managing organizations do not fulfill the needs of rapidly changing environment. Prior studies maintain that a performance measurement and management supports the periodic execution of the same routines in organizations where changes are small or non-existent. In these forms, the role of reflection as an individual, collective or organizational practice is emphasized.

Keywords: Performance management, performance measurement, performance measurement system, performance, innovativeness, reflective practice, organizational learning 
Ukko, J., Hildén, S., Saunila, M. and Tikkamäki, K. (2017) Comprehensive performance measurement and management - Innovativeness and performance through reflective practice, Journal of Accounting and Organizational Change, 13 (3): 425-448.

\section{Introduction}

In developed markets, there is concern regarding the slowing growth of national economies, as well as the capability of these economies to regenerate themselves. The traditional means of improving operational efficiency or cost-effectiveness, such as cutting expenses, do not offer sustainable solutions for these problems since the emerging markets will still hold the advantage in the future. When focusing on the level of the firm, current literature highlights the importance of developing an organization's innovativeness; the ability to innovate is generally accepted as a critical success factor for the growth and future performance of firms (Henri, 2006; Carayannis and Provance, 2008; Muller et al., 2005). Innovativeness is also considered to be the only means by which companies can sustain their competitive advantage (Carayannis and Provance, 2008; Muller et al., 2005) and, therefore, it should be especially emphasized in developed markets.

New ideas and innovations can be traced back to an organization's learning skills and outcomes at the individual, group, and structural levels. Thus, reflective practice plays an essential role in workrelated learning. One of the critical yet largely unexplored issues is how a set of performance measurement and management tools can be used to create learning opportunities (e.g., Englund and Gerdin, 2015; Franco-Santos et al., 2012; Ferreira and Otley, 2009; Chenhall, 2003). Many prevailing approaches to management accounting and performance management highlight the need for learning. This has also been emphasized by Otley (1999) who suggests that performance management aims to focus employee attention and motivate behavior toward the ultimate purpose of implementing an organization's strategy. It has also been stated that broader conceptualizations of control can include factors such as strategic development, strategic control, and learning processes, all of which are typically beyond the scope of management accounting (Malmi and Brown, 2008; Merchant and Otley, 2007). According to Ferreira and Otley (2009), performance management can originate from purposes and objectives. Performance management includes, "evolving formal and informal mechanisms, processes, systems, and networks used by organizations for conveying the key objectives and goals, for assisting the strategic process and ongoing management, and for supporting and facilitating organizational learning and change" (Ferreira and Otley, 2009). Broadbent and Laughlin (2009) state that performance management is often used in the context of human resources in relation to controlling employee behavior, and the influencing role of performance management is as much about behavioral approaches as it is about systems approaches. For example, Mahama's (2006) research shows that a performance measurement system (PMS) helps ensure that performance information is distributed fairly among participants in the supply relationship, which enables learning and problem solving. Further, the impact of a PMS on managers' decision-making processes, learning, and self-monitoring has also received attention in the literature (Franco-Santos et al., 2012). Tuomela (2005) suggests that a 
Ukko, J., Hildén, S., Saunila, M. and Tikkamäki, K. (2017) Comprehensive performance measurement and management - Innovativeness and performance through reflective practice, Journal of Accounting and Organizational Change, 13 (3): 425-448.

PMS helps managers learn how to best improve their performance when appropriate feedback mechanisms are in place. According to Hall (2011), PMSs support managers in confirming their mental models of how their business operates and also enables them to build new mental models. It has also been found that managers consider PMSs useful for monitoring their own performance and for making decisions (Wiersma, 2009). In summary, Bititci et al. (2012) suggest that understanding performance measurement as a social and learning system is a grand challenge that the performance measurement research community needs to address in an integrated manner.

The question, then, is how organizations might utilize PMSs for learning in a way that supports innovativeness and performance in the long term. The idea of organizational learning modifies the role of learning because the development of human resources has traditionally been assigned to human resource departments. The current study suggests that learning should be integrated with performance management.

Furthermore, this paper explicates and highlights the critical role of reflective practices in supporting innovativeness and performance in organizations. Scientists and practitioners are realizing that both future productivity and substantial innovation will rely on firms' capacities to sustain human motivation, commitment, individual and collective ability, as well as their willingness to rethink old habits (Weehuisen, 2011). Consequently, practitioners are searching for interventions that can bring about the greatest increases in motivation, commitment, and the ability to generate fresh ideas. Interventions that are generally used in competence development emphasize task-related knowledge development, structured training programs, and classroom sessions. The benefits gained from these kinds of investments seem to be evident. However, there is a growing interest in learning methods that enhance not only employee knowledge and skills but also more personal traits, such as the ability to practice professional self-reflection and conduct creative dialogue. Organizations need to ensure that they can actively search for new perspectives and critically question old assumptions. They must also enhance their ability to pose and solve problems. Such critical questioning, a meta-skill of reflectivity, has been recognized in research, but its connection to the development of PMSs is still unclear (Nesbit, 2012; Woerkom, 2004).

The development of individual and collective reflectivity is generally thought to result in organizational renewal and innovativeness, which can further improve business and financial performance. However, more in-depth research is needed to understand how to develop and exploit reflective practices in ways that improve innovation and performance. Many studies have focused on the relationship between performance management and performance, but none of them have been able to provide unanimous evidence of this (cf. Franco-Santos et al., 2012; Chenhall, 2003). This study will focus on how performance management can contribute to both the development 
Ukko, J., Hildén, S., Saunila, M. and Tikkamäki, K. (2017) Comprehensive performance measurement and management - Innovativeness and performance through reflective practice, Journal of Accounting and Organizational Change, 13 (3): 425-448.

and management of individual and group reflective skills. Furthermore, it will demonstrate how reflective practices are a crucial element of organizational learning with respect to innovativeness and enhanced performance.

This paper answers the following research question: How can organizations exercise performance management through reflective practice to foster innovativeness and performance? The study includes a literature review that aims to explain and understand the relationships between the concepts particular to this study. It also presents interventionist case studies prepared to understand the interconnections between theory and practice. Finally, this paper ends with the conclusions and an outline of the scope for further research.

\section{Definition of concepts}

\subsection{Organizational learning}

The objective of competence development intervention is to develop the knowledge, skills, and abilities related to tasks at hand and to recognize the capabilities needed for a firm's future survival and success. Because the necessary knowledge and skills are continuously changing, and because predicting critical future capabilities is difficult, the greatest challenge rests in creating learning opportunities at all organizational levels. There are numerous definitions for learning that occurs in an organizational context. In the 1990s, there were many studies concerning learning organization within companies (e.g., Pedler et al., 1997; Senge, 1990). Organizational learning was understood as facilitating members' learning and as continuously evolving (Pedler et al., 1997). The classical definition by Senge (1990) emphasizes five main characteristics of organizational learning - systems thinking, personal mastery, mental models, a shared vision, and team learning. Organizational learning, a term originally introduced in the 1970s by Chris Argyris and Donald Schön (1978), is also an essential concept within current research. It has been argued that "organizational learning is the activity and the process by which organizations eventually reach the ideal of a learning organization" (Finger and Brand, 1999). But what kinds of activities and processes are needed for innovativeness and improved performance? Clearly, adaptive learning (single-loop learning) is not enough because it focuses on solving problems in the present without examining the appropriateness of current learning behaviors. Innovation necessitates a fundamental questioning of the assumptions that underlie the existing ways of working, experimenting, and creating. If single-loop learning is like a thermostat, double-loop learning works by adjusting the frequency and duration of your heater or air conditioner to maintain the desired temperature. The highest form of organizational learning is deutero-learning (Argyris and Schön, 1996). It involves asking more and more fundamental questions and reflecting on previous 
Ukko, J., Hildén, S., Saunila, M. and Tikkamäki, K. (2017) Comprehensive performance measurement and management - Innovativeness and performance through reflective practice, Journal of Accounting and Organizational Change, 13 (3): 425-448.

learning contexts. In addition to governing values, it focuses on questioning embedded traditions and systems. This dimension of learning is composed of structural and behavioral components that determine how learning takes place; it can be also called generative or transformational learning.

An organization learns only through its members, because all learning is done by its individual members. Human learning in the context of an organization is very much influenced by the organization; in turn, it has consequences for the organization and has an impact at the organizational level (Simon, 1991). Based on the above, organizational learning refers to the activity and the process by which organizations utilize human knowledge to improve and gain experience.

\subsection{Reflective practice}

A critical element of transformational learning is reflection (Mezirow, 2000). This is a broadly discussed concept, found everywhere from Dewey's (1938) idea of “learning-by-doing” to Kolb's (1984) experiential learning cycle. Today, reflective practice is highlighted as playing a central role in workplace and organizational learning models (Elkjaer, 2001; Jordan, 2010; Jordi, 2011; Raelin, 2001; Vince, 2002; Nicolini et al., 2011). Reflection is the process of questioning one's intuitive understandings, conducting on-the-spot experiments, and engaging in thoughtful dialogue with others about their circumstances (Schön, 1983). If innovativeness requires the ability to rethink, reflection represents a complex mental process - one first becomes aware of old meanings; explores alternative interpretations; and finally shifts his or her modes of thinking, feeling, and acting. Though reflection is widely accepted as a theoretical construct, relatively few studies have investigated ways of organizing reflective practices within real-life organizations. Nor has anyone studied what kind of potential it holds for innovativeness and performance. Reflection itself is not merely a cognitive process - it incorporates emotions, subconscious elements, and active experimentation. Some recent research does differentiate between reflectivity (in-action/onaction), reflexivity, and diffraction, based on the ontology of the concepts and the metaphors they represent (see Keevers and Treleaven, 2011). However, this study prefers to follow the general development of learning theory, and posits that the existing concept can be further developed without inventing new terminology. Boud (2010) calls for further thinking about reflection that recognizes the complexities and the relational qualities of practice.

This study attempts to better understand how reflection translates into an inquiring attitude and a willingness to change one's actions in the midst of routine work. Thus, in this paper, reflective practice refers to the actual ways in which reflection manifests itself through individual and collective action within the organizational realm. In practice, this means that members of the 
Ukko, J., Hildén, S., Saunila, M. and Tikkamäki, K. (2017) Comprehensive performance measurement and management - Innovativeness and performance through reflective practice, Journal of Accounting and Organizational Change, 13 (3): 425-448.

organization learn and are encouraged to pay attention, slow down in order to engage in dialogue, and explore the connections between and the consequences of various actions. This requires analyzing the role of reflection in relation to learning and performance at the distinct levels of individual, group, and organization (cf. Hildén and Tikkamäki, 2013). Though reflection is discussed within various theoretical fields, what is still missing is a more holistic managerial perspective. Indeed, the interaction between reflective learning and managerial authority is potentially significant to both learning and management theory.

\subsection{Innovativeness}

Innovativeness is the successful management of innovation (Smith et al., 2008). Innovation can be regarded as an organizational capability because it is a process whereby resources are deployed to foster new abilities that create value. Innovativeness is seen as a critical source of competitive advantage in an increasingly changing environment (Tushman and O'Reilly, 1996). Some even argue it is the most important determinant of a firm's performance (Mone et al., 1998). A search of the word "innovation" among academic publications yields tens of thousands of articles, wherein the definitions of the term vary depending on what aspect of innovation is being highlighted (Anderson et al., 2004; Camison-Zornoza et al., 2004; Garcia and Calantone, 2002; Gopalakrishnan and Damanpour, 1997; Hansen and Wakonen, 1997; Landry et al., 2002, in Crossan and Apaydin, 2010). Quite often, it is seen in the literature that organizational learning is a key requirement for the kind of creativity that innovativeness demands. Martins and Terblanche (2003) argue that creating and maintaining an innovative culture requires inquisitiveness, dialogue, updated knowledge and skills, and creative thinking. Though Martins and Terblanche (2003) present learning as only one behavioral aspect that supports a culture of innovation, they do not comprehensively explain the actual process whereby continuous learning and innovation fit together. The modern understanding of work-related learning does not consider learning as a dualphase process through which one acquires certain skills and then uses them within a work context. In this paper, innovation is considered to be a form of continuous learning that represents a work practice and style in which new ideas have room to emerge, be experimented with, and develop.

Innovation may occur in every aspect of an organization's operations and can therefore be classified by organizational function (Yang et al., 2009). Firms can follow different innovation paths. For example, manufacturing firms can develop new products, new product-related services, introduce new manufacturing technologies, and implement new organizational concepts. Each of these innovation types (product, process, and organizational) can itself be a source of competitive advantage (Kirner et al., 2009). Product innovations, which cover both goods and services, can utilize new knowledge or technologies, or they can be based on new uses or combinations of 
Ukko, J., Hildén, S., Saunila, M. and Tikkamäki, K. (2017) Comprehensive performance measurement and management - Innovativeness and performance through reflective practice, Journal of Accounting and Organizational Change, 13 (3): 425-448.

existing knowledge or technologies. A process innovation refers to the implementation of a new or improved production or delivery method. Organizational innovation refers to the renewal of organizational routines, procedures, mechanisms, systems, etc., to promote teamwork, information sharing, coordination, collaboration, learning, and innovativeness (Gunday et al., 2011). Factors that foster innovativeness include, for example, shared vision, leadership, the will to innovate, appropriate organizational structure, key individuals, effective collaboration, continued individual development, extensive communication, external focus, a creative climate, and learning organization (Tidd et al., 2005). By drawing different definitions together, innovation in the context of this research can be thought of in its broadest sense-innovation is a process and outcome, and innovativeness is the successful management of both process and outcome.

Process innovation remains understudied, as most people approach innovation as an outcome (Crossan and Apaydin, 2010). Based on an extensive literature review, Crossan and Apaydin (2010) propose that five managerial levers enable core innovation processes - mission, goals, and strategy; structure and systems; resource allocation; organizational learning and knowledge management tools; and organizational culture. Insofar as innovativeness can be regarded as a mediator of performance (Crossan and Apaydin, 2010), learning is a mediator of innovativeness. From the point of view of learning and innovation, organizational architecture is a key factor for fostering innovation that includes informal structures, response time, and free sharing of information. The manager's role in protecting, appropriating, and exploiting resources for innovation is crucial (Kay, 1993).

\section{Theoretical framework}

The following sections describe the interplay between organizational learning through reflective practice and performance management. More specifically, they discuss the current understanding of the notion of reflective practice in performance management and its role as a mediator for innovativeness and performance (Figure 1). 
Ukko, J., Hildén, S., Saunila, M. and Tikkamäki, K. (2017) Comprehensive performance measurement and management - Innovativeness and performance through reflective practice, Journal of Accounting and Organizational Change, 13 (3): 425-448.

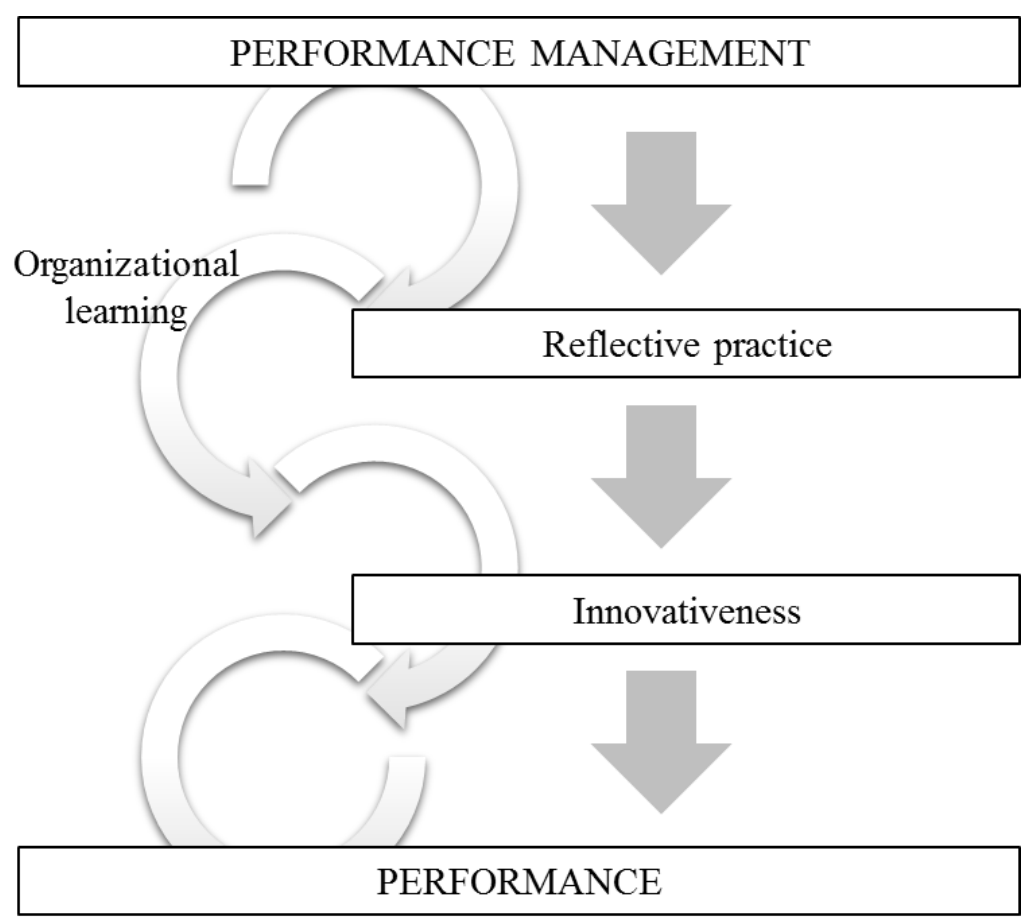

Figure 1. Research framework

\subsection{Reflection in organizational learning theories}

Although it now seems to be common knowledge that organizational learning includes both learning and performance (Gilley and Maycunich, 2000), theories on work-related learning are still dominated by an output approach, and the processes and their contingencies within the organizational institutions remain fairly unexplored.

Adult learning theory and organizational learning are both concerned with adult learning processes, which play a central role in renewal and innovation. But where adult learning theory concentrates more fully on individual learning outcomes, organizational learning deals with the division between individual and organizational outcomes. The concept of reflection, as developed within adult learning theory, contributes to organizational learning by showing the significance of both problem solving and problem posing for individual and organizational performance (Woerkom, 2004).

Lately, organizational learning research has tried to combine theories of adult learning and education within the management context. However, learning organization theorists argue that there has been considerable conceptual confusion about the nature of learning at the organizational 
Ukko, J., Hildén, S., Saunila, M. and Tikkamäki, K. (2017) Comprehensive performance measurement and management - Innovativeness and performance through reflective practice, Journal of Accounting and Organizational Change, 13 (3): 425-448.

level (e.g., Argyris and Schön, 1978, 1996; Brown and Duguid, 1991; Fiol and Lyles, 1985; Gephart et al., 1996; Miner and Mezias, 1996; Yang et al., 2004).

Nonaka et al. (2000) examine the dynamic process of creating and managing knowledge as a conversation between explicit and tacit knowledge. This transformation of information into knowledge occurs through socialization, externalization, combination, and internalization. The creation of knowledge is contextual and takes place in particular learning spaces. Boland and Tenkasi (1995) suggest that communities of knowing promote the organizational processes of perspective-making and perspective-taking. These communities promote narrativity, interpretation, and the representation of knowledge. Based on Tikkamäki (2006), organizational spaces of learning can be called communities of learning where the processes of participation, knowing, social support, and reflecting enable and promote collective learning processes.

Although much is known about individual and collective learning processes, there is no consensus on what kind of framework is most suitable for analyzing the structural, or systemic, level of learning. The practice-based approach to reflective learning assumes that research most likely benefits from a framework that discusses managerial tools (i.e., concrete ways to manage and control learning). There are some examples of the relationship between reflective practice and performance management (e.g., Saunila et al., 2015). Nevertheless, research in performance measurement and management has not often coincided with organizational learning theory. We propose that PMSs offer an incisive and practical framework for understanding organizational learning possibilities in developing opportunities for organizing reflection, learning, and innovation.

\subsection{Performance management research complements organizational learning}

Based on a comprehensive literature review conducted by Bititci et al. (2012), the performance measurement and management field appears to have developed over a number of phasesproductivity management, budgetary control, integrated performance measurement, and integrated performance management. In regard to integrated performance management, a general descriptor of performance management can be used to capture a holistic approach to the management and control of organizational performance. This means that performance management systems include all aspects of organizational control, including those under the heading of management control systems (cf. Ferreira and Otley, 2009).

Contingency-based research has a long tradition in the study of performance management. Researchers have attempted to explain the effectiveness of PMSs by studying system designs that 
Ukko, J., Hildén, S., Saunila, M. and Tikkamäki, K. (2017) Comprehensive performance measurement and management - Innovativeness and performance through reflective practice, Journal of Accounting and Organizational Change, 13 (3): 425-448.

best suit an organization's environment, technology, size, strategy, and national culture. Simply put, a good fit between a PMS and its context results in enhanced performance, while a poor fit leads to a diminished performance (Chenhall, 2007). A more constructivist approach, drawing on a pragmatic perspective (e.g., Schatzki, 2002), argues that managers are less concerned with the technical finesse or comprehensiveness of PMSs (Ahrens and Chapman, 2004, 2007; Dambrin and Robson, 2011; Hall, 2010), especially if they are allowed to handle performance indicators in a flexible way and treat them as means rather than ends (Jordan and Messner, 2012). Managers are seen as active users of PMSs, and enabling systems help them attain their objectives. Adler and Borys (1996) argue that enabling systems allows users to repair the systems by themselves in case of a breakdown or problem. This means that managers have permission to modify a PMS if necessary (Wouters and Wilderom, 2008). Internal transparency permits managers to understand the logic of the system. Global transparency denotes the extent to which managers are allowed to understand the larger implications of their work. Enabling systems also permit some flexibility in terms of how they are used.

The linkage between organizational learning and performance has been quite well established in the current literature (Guest, 2011). Still, performance management literature has not paid extensive attention to human resource issues. According to Fitzgerald et al. (1991), performance management involves the management of results (ends) and the determinants of these results (means). The need for aligning human resource-based performance management systems with organizational PMSs has led to new perspectives on performance management, including teaming measures and managerial measures (Bititci et al., 2012). Furthermore, Broadbent and Laughlin (2009) state that a PMS is often used to control employee behavior. They suggest that a PMS can be seen as a tool of power and authority to direct the behavior of organizations (Broadbent and Laughlin, 2009).

According to Gunday et al. (2011), organizations develop their innovativeness to increase business performance. A large number of studies focusing on the innovation-performance relationship suggest that higher innovativeness increases organizational performance (Gunday et al., 2011; Hult et al., 2004; Calantone et al., 2002). On the one hand, different types of innovations may affect different fields of performance. Certain types of innovations may act as prerequisites for and facilitators of other types of innovations and thus be antecedents to performance. All in all, the link between innovativeness and performance is well established in current literature. However, the mechanisms connecting these two concepts have not been scrutinized. Innovativeness and performance are connected, but it is still unclear what practices and processes lead to the emergence of innovativeness as a firm asset. 
Ukko, J., Hildén, S., Saunila, M. and Tikkamäki, K. (2017) Comprehensive performance measurement and management - Innovativeness and performance through reflective practice, Journal of Accounting and Organizational Change, 13 (3): 425-448.

Moreover, performance management research identifies the role of performance management systems in enabling innovativeness. Simons' (2000) control framework suggests that the interactive use of a control system contributes to successful innovation. The style by which a PMS is used as part of performance management seems to be crucial when aiming for higher performance through innovation. Simons makes a distinction between diagnostic control systems (used on a limited basis to monitor and reward the achievement of specified goals through the review of critical performance variables and/or key success factors) and interactive control systems (used to expand opportunity-seeking and learning). Interactive control systems provide top management with the opportunity to debate and challenge underlying assumptions and action plans. This helps them direct organizational attention and facilitate organizational learning and the formulation of strategies (Simons, 2000; Bisbe and Otley, 2004). According to Bisbe and Otley (2004), the relationship between product innovation and performance is, in fact, more positive when PMSs are used interactively. The diagnostic use of PMSs negatively affects innovativeness, whereas the interactive use of PMSs fosters innovativeness (Henri, 2006). It is clear that performance management facilitates the determinants of innovation (Janssen et al., 2011; Pitt and Tucker, 2008, Saunila and Ukko, 2013). The determinants are the factors that act as either enablers or obstacles of organizational innovativeness. However, performance management theory is relatively silent about the human processes through which interaction takes place. Fruitful and insightful debate requires reflective attitudes and practices.

This study suggests that it is not enough to focus on either individual and team measures or on employees' behavior. A more in-depth approach to the relationship between learning and performance management is needed. It is essential to integrate performance management in organizational learning in a way that takes into account how reflective practice and organizational learning support innovation and higher levels of performance.

\subsection{The role of reflection in innovativeness and performance}

As reflective practice aims for employee development, it intersects with the performance management approach that includes creating a set of practices that engender feelings of perceived justice amongst employees and leads to increased levels of employee commitment (Farndale et al., 2011). In addition, performance management can act as an important tool to manage and develop reflective work practices in order to attain performance goals (Saunila et al., 2015). This can be realized through improving knowledge, competencies, skills, and attitudes, because of their importance in improving the overall efficiency and effectiveness of the organization (cf. Gilley and Maycunich, 2000; Biron et al., 2011; Ulrich, 2013). Reflective work practices can sharpen professionals' perceptions of their methods and approaches to challenging situations, identify the 
Ukko, J., Hildén, S., Saunila, M. and Tikkamäki, K. (2017) Comprehensive performance measurement and management - Innovativeness and performance through reflective practice, Journal of Accounting and Organizational Change, 13 (3): 425-448.

gaps between theory and practice, help evaluators improve their professional practice through critical thinking and decision-making, and increase job satisfaction (e.g., Page and Meerabeau, 2000; Saunila and Ukko, 2015; Smith et al., 2015).

Prior research has indicated innovativeness as one of the outcomes of reflective practice. As learning is concluded to be crucial to attaining higher levels of innovativeness (e.g., Hult et al., 2004), and learning always requires reflection, reflection can thus be considered a key issue when promoting innovativeness. All in all, there are many similar factors underlying reflection and innovativeness. These include, for example, individual skills and capabilities, collective culture, and structural aspects. There are some examples in the current literature suggesting that team reflection is a driver of both team innovation (Somech, 2006) and product innovation (Tien-Shang Lee, 2008). According to Somech (2006), the process of team reflection serves as a vehicle through which the interaction of participative leadership style and functional heterogeneity enhances team innovation. Also, reflective project leadership, meaning questioning one's own leadership behavior, can be a way for a project leader to promote innovativeness (Ollila, 2000).

Innovativeness is suggested to be an organization's means to enhance its business performance (e.g., Gunday et al., 2011). The majority of the previous research on the relationship between innovation and performance agrees that innovation influences performance positively (c.f., Aragón-Correa et al., 2007; García-Morales et al., 2007; Jiménez-Jiménez and Sanz-Valle, 2011; Hashi and Stojčić, 2013, Kilic et al., 2015). Different kinds of innovations may have an effect on different fields of performance. For example, Laforet $(2011 ; 2013)$ found that organizational innovations result in enhanced productivity, profit margins, market share, market leadership, company image, and reputation. Meanwhile, it also improves the working environment, employee satisfaction, and the ability to operate outside the core competency. All in all, the link between innovativeness and performance is well embodied in the current literature. However, the role of reflective practice in this context has not been tracked. This particular relationship has not accounted for the very distinct analytical levels of individual, group, and organization. However, there are similarities regarding the antecedents and nature of the concepts as well as previous research on team reflection, which establishes the connection between the phenomena.

\section{Research methodology}

The research process began with an extensive review of literature on the interface of performance management and organizational learning research. The aim was to explain and understand the relationships between these two fields. The results of the literature review have been supplemented with interventionist case studies. Case studies were deemed appropriate for the importance of the 
Ukko, J., Hildén, S., Saunila, M. and Tikkamäki, K. (2017) Comprehensive performance measurement and management - Innovativeness and performance through reflective practice, Journal of Accounting and Organizational Change, 13 (3): 425-448.

phenomena in practice, due to the lack of existing theory, and because of the exploratory nature of the research. The three selected organizations all represent different fields of operation. Case 1 is a nonprofit healthcare organization with 160 employees. Case 2 is an affiliate of a large, global pharmaceutical company with 150 employees. Case 3 is a local outlet of a consumer retail chain. In the case interventions, "spaces" were constructed for reflective practice and to observe whether and how the interventions reach the level of open and influential reflective practice. In addition, the study has attempted to identify and develop reflective tools to share the researchers' grounds for thinking, thus producing more creative and multifaceted ideas.

\subsection{Case descriptions: Studying reflective practice in practice}

Case 1 is a nonprofit healthcare organization with 160 employees. The management team has noted that this type of organization requires a dramatically different kind of competence development plan. It has become obvious that the workforce's technical expertise is good, but it faces essential challenges related to issues such as multi-professional cooperation, shared expertise between generations, and skills related to customer and partner interface. Professional self-reflectivity is seen as a crucial skill. They launched a reflective competence-scanning tool with an integrated process to facilitate peer discussion and the formulation of competence development plans. This reflective practice captures individual reflection through a web survey focused on the critical new competencies and reflective capacity. This self-evaluation was followed by a peer discussion to engage employees in a collective sharing of meanings and experiences. The evaluation of organizational reflectivity will be institutionalized as a regular practice. They also included two pilot groups for developing a practice to collectively tackle the challenges related to partnering with customers. In this way, they created a basis of forming multi-professional learning groups.

Case 2 is an affiliate of a large global pharmaceutical company. The company is trying to deal with the challenge of localizing a new global strategy, including making a large cultural change. In this organization, the idea for increasing reflectivity is intuitively seen as a useful tool for tackling the complexity of the matrix organization and frequent changes in the market. Their methods of integrating reflective practice in everyday work included reflective manager meetings, where different kinds of reflective methods were utilized to get as much as possible out of the gatherings. In addition, reflective learning groups and coaching were utilized to enhance individuals' (middle managers') reflective capacity and offer a forum for reflecting on personal, team, and organizational performance. The managers were also observed in their everyday work to see how they actively test and translate their learning from coaching into practice. 
Ukko, J., Hildén, S., Saunila, M. and Tikkamäki, K. (2017) Comprehensive performance measurement and management - Innovativeness and performance through reflective practice, Journal of Accounting and Organizational Change, 13 (3): 425-448.

Case 3 is a local outlet of a consumer retail chain. The outlet is part of a large parent company operating in construction, decoration, and gardening, and has approximately 70 employees. Case 3 has implemented an operational change that required sales personnel to spend significantly more time directly with customers. This implies an identity change and requires new competencies and attitudes. Top management is calling for a new kind of "shopkeeper identity". They launched a mentoring program in which technical product and sales know-how is shared through organized peer sessions. In addition, the organization holds organized team meetings during which relevant accounting information is shared and collectively reflected upon to establish the shopkeeper's visibility and responsibility. Also, suitable financial and non-financial metrics were developed to support this reflective practice.

\subsection{Phases of data collection}

\section{Phase 1. Survey}

A questionnaire was drafted based on the reflective process at the individual, group, and organization levels. It included 15 items intended to measure reflective practice (adopted from Hildén and Tikkamäki, 2013). A Likert-type scale ranging from "strongly disagree" to "strongly agree" was used. The neutral response "neither disagree nor agree" was provided as an option to reduce uninformed responses. The questionnaire is presented in the Appendix. The goal of the first phase of the research was to form an understanding of the state of reflection and reflective practices to define what exactly is being developed and evaluated. To this end, the respondents were asked to indicate their views on 15 items of reflective practice (at individual, group, and organizational levels). The data was analyzed by calculating means and thereby forming an understanding of the current state of reflective practice in each organization. To achieve an overall view of the state of reflective practice, all of the organizations' personnel were asked to fill in the survey. A total of 267 valid responses were received. This indicates a response rate of 70 percent.

\section{Phase 2. Interventionist case studies}

The interventionist case studies aimed to help organize a reflective dialogue and observe whether and how it reaches the level of open and influential interaction. They also helped identify and develop tools to share the grounds for this study's perspective, thus producing more creative and multifaceted ideas. In each case organization, interventions were organized as workshops focused on the following themes - culture, planning, measurement, rewards, and work organizing. Interventions were planned to ensure that the reflective practice at work is related to the organizations' change and development challenges in those areas. Reflective capacity (individual- 
Ukko, J., Hildén, S., Saunila, M. and Tikkamäki, K. (2017) Comprehensive performance measurement and management - Innovativeness and performance through reflective practice, Journal of Accounting and Organizational Change, 13 (3): 425-448.

level reflection) was facilitated through different kinds of writing tasks and learning diaries related to the interventions' themes, which aimed to prepare participants for the reflective meetings and discussions. Through various tasks, the participants become conscious of their presumptions and point of views related to the selected themes, and they generated relevant and daily work-fit material to be reflected upon collectively. Reflective dialogue (group-level reflection) was promoted through various learning groups that served as forums for sharing expertise and negotiating. Reflective management control (organization-level reflection) was supported by linking the reflective learning groups and task themes to the accounting information and knowledge related to other forms of control (e.g., reward and planning systems, cultural controls, etc.). Suomala et al. (2014) concludes that successful interventionist research requires issues that are perceived relevant for both parties and demands an active stance from researchers, who should be ready and able to construct a common ground and interesting questions, rather than being content to just find them. In this study, therefore, performance management was expected to foster innovativeness and performance through reflective practices and learning. The practices were employed based on the expertise of the researchers, which emphasized the active stance of the researchers during the research. In Case 1, managers taking part in the learning groups were asked to share their understanding about the forms of control. In Case 2, one aim of the management team's learning group was to generate a collective sense of the financial and non-financial metrics and to develop them further in line with the organization's strategic goals. In Case 3, financial and non-financial metrics were developed to support reflective practice. Lukka (2014) concludes that interpretive research profoundly investigates how associations between phenomena occur and explores the processes and mechanisms that generate outcomes from particular conditions, thereby shedding light on the 'arrows' between variables. In this study, the influences of studied practices have been presented through explanations of how the results were achieved and what issues hindered the expected results under the prevailing conditions.

\section{Phase 3. Survey}

In Phase 3, the questionnaire was administered again in order to track the changes in reflection and reflective practices. In addition, items of innovativeness (presented in the Appendix) were added to trace the connection between reflective practice and innovativeness. A total of 175 valid responses were received in the second round of the survey. The data was analyzed by calculating means and comparing them to the means of the previous survey. In addition, correlations between the items of reflective practice and the items of innovativeness were analyzed.

Phase 4. Interviews 
Ukko, J., Hildén, S., Saunila, M. and Tikkamäki, K. (2017) Comprehensive performance measurement and management - Innovativeness and performance through reflective practice, Journal of Accounting and Organizational Change, 13 (3): 425-448.

In the fourth phase of the study, group interviews were conducted in the case organizations. Representatives of all levels of the organizations were interviewed to achieve an inclusive perspective of the outcomes of the reflective practice. The interviewees included top managers and middle managers from different units and departments. In Case 1 and Case 3, employee representatives also participated in the interviews. The interviews focused on the same three levels of reflective practice that were utilized in the two survey rounds.

Although the interview questions were determined in advance, the discussions were informal and were facilitated through supporting questions and comments made by the researchers. This enabled an in-depth understanding of the phenomenon under investigation. The core questions of the semistructured interviews were as follows: What kind of effects have you noticed as a result of the development actions in your everyday work - either in your own experience or more broadly in your company? If your company learned to act in a distinctly more reflective way, what would happen?

Table 1. The research process - phases and utilized data

\begin{tabular}{|c|c|c|c|c|c|}
\hline & & Case 1 & Case 2 & Case 3 & Main results \\
\hline $\begin{array}{l}\text { Phase } 1 . \\
\text { Survey }\end{array}$ & $\begin{array}{l}\text { Reflection at individual, group, } \\
\text { and organizational levels } \\
\text { The scale was 1-5, from } \\
\text { strongly agree to strongly } \\
\text { disagree. }\end{array}$ & $\begin{array}{l}107 / 160 \\
\text { responses }\end{array}$ & $\begin{array}{l}103 / 150 \\
\text { responses }\end{array}$ & $\begin{array}{l}57 / 70 \\
\text { responses }\end{array}$ & $\begin{array}{l}\text { Individual skills and willingness } \\
\text { to reflect are high, but structures } \\
\text { seem to lag behind. }\end{array}$ \\
\hline $\begin{array}{l}\text { Phase } 2 . \\
\text { Interventionist } \\
\text { case studies }\end{array}$ & $\begin{array}{l}\text { Workshops on the following } \\
\text { themes: } \\
\text { - Culture } \\
\text { - Planning } \\
\text { - Measurement } \\
\text { - Rewards } \\
\text { - Work organizing }\end{array}$ & $\begin{array}{l}5 \text { workshops } \\
\text { with managers } \\
\text { and } \\
\text { employees }\end{array}$ & $\begin{array}{l}5 \text { workshops } \\
\text { with managers } \\
\text { and employees }\end{array}$ & $\begin{array}{l}4 \text { workshops } \\
\text { with managers } \\
\text { and } \\
\text { employees }\end{array}$ & $\begin{array}{l}\text { Performance management and } \\
\text { control should acknowledge } \\
\text { reflective practices } \\
\text { Reflective practices are related to } \\
\text { learning multiple forms of } \\
\text { control (e.g., reward and } \\
\text { planning systems, cultural } \\
\text { controls) }\end{array}$ \\
\hline $\begin{array}{l}\text { Phase } 3 . \\
\text { Survey }\end{array}$ & $\begin{array}{l}\text { Reflection at individual, group, } \\
\text { and organizational levels } \\
\text { Innovativeness } \\
\text { The scale was 1-5, from } \\
\text { strongly agree to strongly } \\
\text { disagree. }\end{array}$ & $\begin{array}{l}79 / 160 \\
\text { responses }\end{array}$ & $\begin{array}{l}47 / 150 \\
\text { responses }\end{array}$ & $\begin{array}{l}49 / 70 \\
\text { responses }\end{array}$ & $\begin{array}{l}\text { Managers' reflective practice } \\
\text { skills were improved } \\
\text { Reflection at individual, group, } \\
\text { and organizational levels is } \\
\text { connected to innovativeness }\end{array}$ \\
\hline $\begin{array}{l}\text { Phase } 4 . \\
\text { Interviews }\end{array}$ & $\begin{array}{l}\text { Discussion on the following } \\
\text { subjects: } \\
\text { - Effects of development } \\
\text { actions (interventions) in } \\
\text { everyday work } \\
\text { - Reflection opportunities/risks }\end{array}$ & $\begin{array}{l}\text { Group } \\
\text { interviews } \\
\text { (financial } \\
\text { manager, HR } \\
\text { manager, unit } \\
\text { managers, } \\
\text { employee } \\
\text { representative) }\end{array}$ & $\begin{array}{l}\text { Group } \\
\text { interviews } \\
\text { (HR manager, } \\
\text { team leaders) }\end{array}$ & $\begin{array}{l}\text { Group } \\
\text { interviews } \\
\text { (heads of } \\
\text { units, sales } \\
\text { managers, } \\
\text { employee } \\
\text { representative) }\end{array}$ & $\begin{array}{l}\text { Reflection at its best can improve } \\
\text { innovativeness and performance } \\
\text { Reflection should be targeted and } \\
\text { its objectives should be clear } \\
\text { It requires including PMSs and } \\
\text { related measures to evaluate that } \\
\text { actions taken had the appropriate } \\
\text { impact }\end{array}$ \\
\hline
\end{tabular}

Similar research processes were consequently used in all cases to ensure scientific transparency and repeatability. The data were analyzed in terms of content analysis, and case triangulation was 
Ukko, J., Hildén, S., Saunila, M. and Tikkamäki, K. (2017) Comprehensive performance measurement and management - Innovativeness and performance through reflective practice, Journal of Accounting and Organizational Change, 13 (3): 425-448.

used to validate the findings. In addition, researcher triangulation, theory triangulation, and data triangulation were also used to validate the findings. The research was conducted and data were analyzed with the cooperation of four researchers through content analysis, after which the commonly held view was discussed. In addition, theory triangulation was adopted. The goal of employing different theoretical frameworks was to produce the ability to arrive at new understandings. Although the study belongs to the stream of performance measurement and management research, it also applied organizational learning research to integrate existing theory with new contexts. Data triangulation was used by collecting more than one source of data, and the data collected during the interventions included documented observations of the researchers as well as assignments written by the representatives of the participating companies. The meetings were also recorded to document the data. Afterward, surveys and interviews were conducted to assess the results of the interventions.

\section{Results}

This study focused on how performance management can contribute to both the development and management of reflective practice. Furthermore, it will demonstrate how reflective practices are a crucial element of organizational learning with respect to innovativeness and higher performance. The main results are presented in Table 1.

\subsection{Reflective practice as a skill that can be learned}

The results indicate that reflection is not innate but something that must be learned. The reflective learning groups in the case companies focused on the strategic themes, which also emphasized the reflective practices conducted as well as by introducing the idea of reflection. Based on the feedback of the supervisors, the need for a deeper understanding of the "idea" and "potential" of reflection was a conclusion of a firsthand and personal experiment conducted during the reflective practices. The supervisors also perceived that becoming a reflective leader is possible only through practicing and embracing, for example, meta-level thinking, open questions, self-monitoring, and dialogue. Learning occurs only when we become aware of the impact of our own model of thinking, world of experience, and beliefs about our own practices, which allows us to develop and renew ourselves. The benefits of adopting reflective skills were an enhancement in analytical behavior and a broader scope of thinking - people learned to question their own thinking through adopting a wider perspective. Open questions were set and discussed by interaction partners, which led to more independent thinking and problem-solving, leading to better playing the role of a listener and being truly present in any situation. Reflective practices were perceived to assist one's own professional and personal development. The team leader from case 2 stated, 
Ukko, J., Hildén, S., Saunila, M. and Tikkamäki, K. (2017) Comprehensive performance measurement and management - Innovativeness and performance through reflective practice, Journal of Accounting and Organizational Change, 13 (3): 425-448.

"By using imagination, we can do new things or old things in a new way, if there is enough enthusiasm and one's own abilities are adequate."

A reflective approach to work was found to increase in particular the ability to find new perspectives, the ability to cooperate, the willingness to participate, the creation of a confidential atmosphere for discussion, fostering a sense of dedication, and the ability to make decisions. However, it can be stated that to have an impact on performance, the reflective practices need to be implemented under appropriate circumstances. The main prerequisites for reflection are the right capabilities and resources for working. This means understanding a job description, having the appropriate skills for a job, organizational support, up-to-date tools, and enough time to perform the tasks. For example, a sales manager at case company 3 stated,

\section{"The preconditions for work need to be in one's hands. Then there will be time and energy for reflection and development."}

Furthermore, the cases studies indicate that reflection requires small deeds but great knowledgeit builds relevancy, a feeling of control, and appreciative interaction. During the research, it was seen that the learning of reflective practices created skills and know-how, which had a positive impact on working atmosphere and effectiveness. The key was that employees were confident about the potential of the reflective practices through their personal practices. The supervisors of one case organization decided during the process to increase the systematic exploitation of the open questions during both the formal and informal meetings. They also held back their own opinions and focused on being present and listening. This inspired their employees to solve the challenges more independently and also empowered them. The managers in turn had more time to process their "sparring" approach to work, which had a positive impact on the quality of operations. Many experts introduced a fifteen-minute reflection time during the work day in order to prioritize and focus on a more ambitious workday. The common perception was that clarifying the day's target helped avoid the rush effect and spurred productivity.

Based on the research, the study shows that individual skills and willingness to reflect are high, but the structures seem to lag behind. Managers' reflective practice skills were improved when practicing reflective skills. Reflective practice plays a crucial role in connecting organizational learning with performance goals. If we accept that innovations are an outcome of learning processes, we need to realize that reflection is also required. However, in the sense that it is managed, reflection can also be focused and productive. As an organizational practice, it is not necessarily a "soft" approach. In fact, it is hard work as it forces one to let go of normal and safe 
Ukko, J., Hildén, S., Saunila, M. and Tikkamäki, K. (2017) Comprehensive performance measurement and management - Innovativeness and performance through reflective practice, Journal of Accounting and Organizational Change, 13 (3): 425-448.

assumptions and investigate the unknown. The present research agenda also includes the risks of reflection within particular case studies. In terms of creating powerful organizational stories and personal meaning, reflection offers great potential. It is a source of stronger intrinsic motivation, awareness, and mental agility. However, allowing people to actively search for better solutions may lead to political or other conflicts.

\subsection{Reflective practice enhances innovativeness and performance}

Conceptualizing the innovation process as a type of learning suggests a great potential for managing innovativeness. So far, innovation research has paid very little attention to meaningful and conscious learning - concepts derived from learning theory and psychology that are at the heart of innovation-producing learning. Based on the findings of the case studies, this research proposes that organizations benefit from a deeper understanding of individual and collective learning processes - how thinking transforms, how new interpretations may emerge (exploration), and how routines can be broken or fixed. Human processes are the basis for organizational learning, which often manifests as innovation. As previously mentioned, reflection is an integral learning element. It changes the nature of human thinking (mental models, schemas, etc.). In the case organizations, it was clear that without the time, space, and willingness to question the old habits and ways of doing things, innovation would be unlikely.

Reflective practices observed in the context of the case organizations show that attention is still directed at individual reflective skills. In addition to this individual development, this study suggests two other main levels of development that need to be incorporated to boost innovativeness. Creating organizational learning spaces fosters collective learning processes. The results of the case studies indicate that both group- and organization-level reflective practices have positive impacts on innovativeness. This was realized through the second round of the survey, which found a significant relationship between all levels of reflective practice and innovativeness. The relationship was strongest with organizational level reflective practice and innovativeness. This strengthens the notion that it is specifically group- and organization-level reflection that generates organizational innovations by linking the reflective practices to the strategic goals. An interviewee from case company 1 stated,

"[Apply reflective practice aims to] increase business! After observing the life of the customer companies, it becomes easier to identify the needs of the customers even from small signals."

"[Exploiting reflective practice at work can result in] new customer relationships and ideas as well as new models for operation." 
Ukko, J., Hildén, S., Saunila, M. and Tikkamäki, K. (2017) Comprehensive performance measurement and management - Innovativeness and performance through reflective practice, Journal of Accounting and Organizational Change, 13 (3): 425-448.

As an example of group- and organization-level reflective practices, the findings from Case 3 present factors beyond good financial performance at the company's stores. In comparison to other stores, the studied units set their own targets and made their own decisions alongside the efficiency targets set by the control chain. By allowing them to think about and plan the actions they could perform toward achieving their desired targets, these decisions were made in collaboration with the employees. This group effort helped them avoid redundancies and reorganizing the tasks, which led to an overall perceived better work atmosphere with a motivational aspect that strengthened the commitment of the employees. This in turn promoted the thinking that the work is something that needs to be developed, which manifests as excellent service, a service culture, and positive service experiences (customer satisfaction feedback). The sense of being excellent as sellers was strengthened through the reflective practices.

The results of the study suggest that reflection at the individual, group, and organizational levels is connected to innovativeness. Reflection at its best can improve innovativeness and performance. The case study findings indicate that such improvements require that reflection is targeted and objectives are clear.

\subsection{Performance management as a fuel for reflective practice}

The study also aimed to examine the interlinkage between performance management and reflective practice. It enquired into the circumstances under which performance management can be exploited to facilitate reflective practice in order achieve higher performance. The results supported the notion that reflective practice at an organizational level is crucial for attaining better performance. The results indicate that the development subjects/themes that the reflective practices are intended to influence need to be limited to a few key themes, and the connection to performance needs to be both justified and discussed. This was clear in all three case companies, because the interventions show that the different levels of an organization need their own measures and targets for the selected themes on which the reflective practices are believed to have an effect. Based on the results, it can be shown that performance management and control should acknowledge reflective practices. Reflective practices are related to learning multiple forms of control (e.g., reward and planning systems, cultural controls, etc.). It requires including a PMS and related measures to evaluate if the right things are done in the right way.

Furthermore, as one element of performance management, organizational learning offers considerable investments to increase employees' skills and performance. Thus, based on case analyses, a central challenge of performance management is to respond not only to the present 
Ukko, J., Hildén, S., Saunila, M. and Tikkamäki, K. (2017) Comprehensive performance measurement and management - Innovativeness and performance through reflective practice, Journal of Accounting and Organizational Change, 13 (3): 425-448.

needs of reflective practice but to meet the potential future needs of reflective practice. In fact, staying alert to how reflective practice skills must be developed was a practical challenge for the companies in the case studies. But how does one evaluate the utility and profitability of reflective practice development efforts?

It became apparent in the interventions of all three case companies that investments in human capital are difficult to measure and evaluate because of the complexity of this capital. Cause-andeffect relationships are difficult to locate, and, for that reason, there are few effective practices for measurement and evaluation. However, even if measurement and evaluation are challenging, that is not a sufficient reason not to measure how reflective practice development affects an organization's performance. Managers must be able to evaluate benefits by measuring and evaluating the effects of learning interventions on performance. This will help to create a comprehensive picture of learning mechanisms throughout the organization. As a head of unit of case company 3 stated,

"When a sufficient knowledge [of applying reflective practice] has been secured and indicators for measuring the reflective skills have been created, you can move on to the next stage, the exchange of information and experience among the different levels of the organization."

This paper emphasizes the crucial role of organizational learning in performance management. Such learning ought to take a more active role in planning and modifying an organization's structural issues - in other words, PMSs. Individual and collective willingness to reflect is easily thwarted by poor organization of work as well as misleading performance measurements and incentives. Based on insights derived from the case studies, it was seen that the creation and support of reflective practice should be done through the collaboration of an organization's general management and those responsible for performance management. As today's critical competencies rely on meta-cognitive capabilities, the role of the organizational socio-political reality in which people practice reflection becomes more essential. This is why the role of learning mechanisms, with special regard to complex competencies, should not merely be an exercise in developing reflective individual skills. It is more a multilevel development task, where individual motivation, potential, collective work practices, and means of performance management are intertwined.

\section{Discussion}

This study has demonstrated how reflective practices are a crucial element of organizational learning and further innovativeness and performance. It became apparent that reflection is not innate but a skill that can be learned. The main prerequisites for reflection are the right capabilities 
Ukko, J., Hildén, S., Saunila, M. and Tikkamäki, K. (2017) Comprehensive performance measurement and management - Innovativeness and performance through reflective practice, Journal of Accounting and Organizational Change, 13 (3): 425-448.

and resources for working. This means understanding a job description, having the appropriate skills for a job, organizational support, up-to-date tools, and enough time to perform the tasks. As prior research indicates, these resources enable proper focus, time, and energy for reflection and development at an individual level, which encourages breaking the organizational boundaries and discussing the critical issues, simultaneously initiating change in the old routines (cf. Hildén and Tikkamäki, 2013; Saunila et al., 2015; Saunila and Ukko, 2015). The research results indicate that this can be due to the fact that employees realize the idea and potential of reflection only through their own actions and attempts. It was also found that one can become a reflective supervisor only through practice, and it requires embracing meta-thinking, open-asking as well as self-examination and dialogue. This is in line with the notion of Woerkom (2004) who shows the significance of both problem-solving and problem-posing for individual and organizational performance. This creates new knowledge and skills of reflective practice, as the results of this study show.

When focusing on the role of reflection in innovativeness, the study showed that conceptualizing the innovation process as a type of learning suggests tremendous potential for managing innovativeness. The results are thus in line with Hult et al. (2004), according to which learning is crucial in attaining higher levels of innovativeness, and learning always requires reflection. Reflection can thus be considered a key issue in promoting innovativeness. Further, reflective practices observed in the case studies showed that attention still tends to be directed toward individual reflective skills. However, the results of the case studies indicate that both the groupand organization-level reflective practices have positive impacts on innovativeness. The study thus supports the requirements for reflective practice presented by Hildén and Tikkamäki (2013), which suggests that in addition to this individual development, two other main levels of development need to be incorporated to boost innovativeness. The results also support Somech (2006) who showed that team reflection is a driver for team innovation. Coaching, mentoring, and learning groups emphasize the development of meta-cognitive skills for self-managing and fruitful dialogic interaction (Roffe, 1999). Creating organizational learning spaces fosters collective learning processes. This strengthens the notion that it is specifically the group and organizational reflection that generate organizational innovations by linking the reflective practices to the strategic goals. The result of this study strengthened the notion that reflective practice at an organizational level is crucial for attaining higher performance. Thus, the results are in line with the study of Saunila and Ukko (2015).

In addition the results show that a central challenge of performance management is to respond not only to the present needs of reflective practice, but to meet potential future needs of reflective practice. This challenge takes us back to Simons' (2000) views on interactive management control and how organizations can systematically investigate strategic uncertainties that surround them. In 
Ukko, J., Hildén, S., Saunila, M. and Tikkamäki, K. (2017) Comprehensive performance measurement and management - Innovativeness and performance through reflective practice, Journal of Accounting and Organizational Change, 13 (3): 425-448.

fact, staying alert to how reflective practice skills must be developed is a practical challenge for professionals.

\section{Conclusions}

Organizations can be characterized by more and more advanced learning practices as well as PMSs. Still, the previous sections of this study have shown that there is still a lot of potential for a more sophisticated exploitation of these practices and systems to better compete in global markets. This research has investigated the phenomenon through the following three entities - the nature of applying reflective practice at work, the effects of reflective practice in terms of innovativeness and performance, and the role of performance management in developing reflective practice. The study has three main implications. First, reflective practice can be learned and developed. Second, reflective practice is connected to innovativeness and performance. Third, performance management through PMSs can assist in targeting reflective practice.

This study showed that there are many ways to exploit performance management through reflective practice to foster innovativeness and performance. The study suggests that performance management and organizational learning can be connected in a way that emphasizes the role of reflective practices (at specific organizational levels) in facilitating innovativeness and performance. Based on a theoretical as well as empirical understanding, this study argues that reflective practices can increase performance and innovativeness. It is worth exploring further how reflective practices increase awareness and sensitivity and imbue ordinary information with more meaning, as well as what types of learning phenomena are observable. It is beneficial to capture both positive and negative impacts of reflective learning on organizational performance. This analysis would help better understand what kinds of reflective practices are productive, why, and even cases when perhaps reflection is not always beneficial.

The study argues that more in-depth interventionist research and case studies are needed for a deeper understanding of the mechanisms and arrangements by which PMS and reflective organizational learning can be connected in a way that generates innovativeness and performance. In other words, it is essential to understand how firms can be organized to ensure that organizational learning and reflective practices are not isolated parts of a management system.

\section{References}

Adler, P. S., and Borys, B. (1996). Two types of bureaucracy: Enabling and coercive. Administrative Science Quarterly, pp. 61-89. 
Ukko, J., Hildén, S., Saunila, M. and Tikkamäki, K. (2017) Comprehensive performance measurement and management - Innovativeness and performance through reflective practice, Journal of Accounting and Organizational Change, 13 (3): 425-448.

Ahrens, T., and Chapman, C. S. (2004). Accounting for flexibility and efficiency: A field study of management control systems in a restaurant chain. Contemporary Accounting Research, Vol. 21 No. (2), pp. 271-301.

Ahrens, T., and Chapman, C. S. (2007). Management accounting as practice. Accounting, Organizations and Society, Vol. 32 No. (1), pp. 1-27.

Anderson, N., De Dreu, C. K., and Nijstad, B. A. (2004). The routinization of innovation research: A constructively critical review of the state-of-the-science. Journal of organizational Behavior, Vol. 25(2), pp. 147-173.

Aragón-Correa, J. A., García-Morales, V. J., and Cordón-Pozo, E. (2007). Leadership and organizational learning's role on innovation and performance: Lessons from Spain. Industrial Marketing Management, Vol. 36 No. (3), pp. 349-359.

Argyris, C., and Schön, D. A. (1978). Organizational learning: A theory of action perspective (Vol. 173). Reading, MA: Addison-Wesley.

Argyris C and Schön D (1996) Organizational Learning 2: Theory, Method and Practice. Reading: Addison-Wesley.

Biron, M., Farndale, E., and Paauwe, J. (2011). Performance management effectiveness: lessons from world-leading firms. The International Journal of Human Resource Management, Vol. 22 No. (06), pp. 1294-1311.

Bisbe, J., and Otley, D. (2004). The effects of the interactive use of management control systems on product innovation. Accounting, Organizations and Society, Vol. 29 No. (8), pp. 709-737.

Bititci, U., Garengo, P., Dörfler, V., and Nudurupati, S. (2012). Performance measurement: challenges for tomorrow. International Journal of Management Reviews, Vol. 14 No. (3), pp. 305327.

Boland Jr, R. J., and Tenkasi, R. V. (1995). Perspective making and perspective taking in communities of knowing. Organization Science, Vol. 6 No. (4), pp. 350-372. 
Ukko, J., Hildén, S., Saunila, M. and Tikkamäki, K. (2017) Comprehensive performance measurement and management - Innovativeness and performance through reflective practice, Journal of Accounting and Organizational Change, 13 (3): 425-448.

Boud, D. (2006). Relocating reflection in the context of practice: Rehabilitation or rejection. In Professional Lifelong Learning: Beyond Reflective Practice Conference, Trinity and All Saints College, Leeds.

Broadbent, J., and Laughlin, R. (2009). Performance management systems: A conceptual model. Management Accounting Research, Vol. 20 No. (4), pp. 283-295.

Brown, J. S., and Duguid, P. (1991). Organizational learning and communities-of-practice: Toward a unified view of working, learning, and innovation. Organization Science, Vol. 2 No. (1), pp. 40-57.

Calantone, R. J., Cavusgil, S. T., and Zhao, Y. (2002). Learning orientation, firm innovation capability, and firm performance. Industrial Marketing Management, Vol. 31 No. (6), pp. 515524.

Camisón-Zornoza, C., Lapiedra-Alcamí, R., Segarra-Ciprés, M., and Boronat-Navarro, M. (2004). A meta-analysis of innovation and organizational size. Organization Studies, Vol. 25 No. (3), pp. 331-361.

Carayannis, E. G., and Provance, M. (2008). Measuring firm innovativeness: towards a composite innovation index built on firm innovative posture, propensity and performance attributes. International Journal of Innovation and Regional Development, Vol. 1 No. (1), pp. 90-107.

Chenhall, R. H. (2003). Management control systems design within its organizational context: findings from contingency-based research and directions for the future. Accounting, Organizations and Society, Vol. 28 No. (2), pp. 127-168.

Chenhall, R. H. (2006). Theorizing contingencies in management control systems research. Handbooks of Management Accounting Research, Vol. 1, pp. 163-205.

Crossan, M. M., and Apaydin, M. (2010). A multi-dimensional framework of organizational innovation: A systematic review of the literature. Journal of Management Studies, Vol. 47 No. (6), pp. 1154-1191.

Crossan, M. M., Lane, H. W., and White, R. E. (1999). An organizational learning framework: From intuition to institution. Academy of management review, Vol. 24 No. (3), pp. 522-537. 
Ukko, J., Hildén, S., Saunila, M. and Tikkamäki, K. (2017) Comprehensive performance measurement and management - Innovativeness and performance through reflective practice, Journal of Accounting and Organizational Change, 13 (3): 425-448.

Dambrin, C., and Robson, K. (2011). Tracing performance in the pharmaceutical industry: Ambivalence, opacity and the performativity of flawed measures. Accounting, Organizations and Society, Vol. 36 No. (7), pp. 428-455.

Dewey, J. (1938). Logic: The Theory of Inquiry. New York: Henry Holt and Company.

Elkjaer, B. (2001). The learning organization: an undelivered promise. Management learning, Vol. 32 No. (4), pp. 437-452.

Englund, H., and Gerdin, J. (2015). Developing enabling performance measurement systems: on the interplay between numbers and operational knowledge. European Accounting Review, Vol. 24 No. (2), pp. 277-303.

Farndale, E., Hope-Hailey, V., and Kelliher, C. (2011). High commitment performance management: The roles of justice and trust. Personnel Review, Vol. 40 No. (1), pp. 5-23.

Ferreira, A., and Otley, D. (2009). The design and use of performance management systems: An extended framework for analysis. Management Accounting Research, Vol. 20 No. (4), pp. 263282.

Finger, M. and Brand, S.P. (1999). The concept of learning organization applied to the transformation of the public sector: conceptual contributions for the theory development. In: Easterby-Smith, M., Burgouyne, J. \& Araujo, L. (eds) Organizational Learning and the Learning Organization: Developments in the Theory and Practice. London: Sage.

Fiol, C. M., and Lyles, M. A. (1985). Organizational learning. Academy of Management Review, Vol. 10 No. (4), pp. 803-813.

Fitzgerald, L., Johnston, R., Brignall, T.J., Sivestro, R. and Voss, C. (1991). Performance Measurement in Service Businesses. London: CIMA.

Franco-Santos, M., Lucianetti, L., and Bourne, M. (2012). Contemporary performance measurement systems: A review of their consequences and a framework for research. Management Accounting Research, Vol. 23 No. (2), pp. 79-119. 
Ukko, J., Hildén, S., Saunila, M. and Tikkamäki, K. (2017) Comprehensive performance measurement and management - Innovativeness and performance through reflective practice, Journal of Accounting and Organizational Change, 13 (3): 425-448.

Garcia, R., and Calantone, R. (2002). A critical look at technological innovation typology and innovativeness terminology: a literature review. Journal of Product Innovation Management, Vol. 19 No. (2), pp. 110-132.

García-Morales, V. J., Lloréns-Montes, F. J., and Verdú-Jover, A. J. (2007). Influence of personal mastery on organizational performance through organizational learning and innovation in large firms and SMEs. Technovation, Vol. 27 No. (9), pp. 547-568.

Gephart, M. A., Marsick, V. J., Van Buren, M. E., Spiro, M. S., and Senge, P. (1996). Learning organizations come alive. Training \& Development, Vol. 50 No. (12), pp. 34-46.

Gilley, J.W., and Maycunich, A. (2000). Organizational Learning, Performance, and Change: An Introduction to Strategic Human Resource Development. Cambridge, MA: Perseus Books.

Gopalakrishnan, S., and Damanpour, F. (1997). A review of innovation research in economics, sociology and technology management. Omega, Vol. 25 No. (1), pp. 15-28.

Guest, D. E. (2011). Human resource management and performance: still searching for some answers. Human Resource Management Journal, Vol. 21 No. (1), pp. 3-13.

Gunday, G., Ulusoy, G., Kilic, K., and Alpkan, L. (2011). Effects of innovation types on firm performance. International Journal of Production Economics, Vol. 133 No. (2), pp. 662-676.

Hall, M. (2011). Do comprehensive performance measurement systems help or hinder managers' mental model development?. Management Accounting Research, Vol. 22 No. (2), pp. 68-83.

Hall, M. (2010). Accounting information and managerial work. Accounting, Organizations and Society, Vol. 35 No. (3), pp. 301-315.

Hansen, S. O., and Wakonen, J. (1997). Innovation, a winning solution?. International Journal of Technology Management, Vol. 13 No. (4), pp. 345-358.

Hashi, I., and Stojčić, N. (2013). The impact of innovation activities on firm performance using a multi-stage model: Evidence from the Community Innovation Survey 4. Research Policy, Vol. 42 No. (2), pp. 353-366. 
Ukko, J., Hildén, S., Saunila, M. and Tikkamäki, K. (2017) Comprehensive performance measurement and management - Innovativeness and performance through reflective practice, Journal of Accounting and Organizational Change, 13 (3): 425-448.

Henri, J. F. (2006). Management control systems and strategy: A resource-based perspective. Accounting, organizations and society, Vol. 31 No. (6), pp. 529-558.

Hilden, S., and Tikkamäki, K. (2013). Reflective practice as a fuel for organizational learning. Administrative Sciences, Vol. 3 No. (3), pp. 76-95.

Hult, G. T. M., Hurley, R. F., and Knight, G. A. (2004). Innovativeness: Its antecedents and impact on business performance. Industrial Marketing Management, Vol. 33 No. (5), pp. 429-438.

Janssen, S., Moeller, K., and Schlaefke, M. (2011). Using performance measures conceptually in innovation control. Journal of Management Control, Vol. 22 No. (1), pp. 107-128.

Jiménez-Jiménez, D., and Sanz-Valle, R. (2011). Innovation, organizational learning, and performance. Journal of Business Research, Vol. 64 No. (4), pp. 408-417.

Jordan, S. (2010). Learning to be surprised: How to foster reflective practice in a high-reliability context. Management Learning, Vol. 41 No. (4), pp. 391-413.

Jordan, S., and Messner, M. (2012). Enabling control and the problem of incomplete performance indicators. Accounting, Organizations and Society, Vol. 37 No. (8), pp. 544-564.

Jordi, R. (2010). Reframing the concept of reflection: Consciousness, experiential learning, and reflective learning practices. Adult Education Quarterly, Vol. 61 No. (2): pp. 181-197.

Kay, J. (1993). Foundations of Corporate Success. Oxford: Oxford University Press.

Keevers, L., and Treleaven, L. (2011). Organizing practices of reflection: A practice-based study. Management Learning, Vol. 42 No. (5), pp. 505-520.

Kilic, K., Ulusoy, G., Gunday, G., and Alpkan, L. (2015). Innovativeness, operations priorities and corporate performance: An analysis based on a taxonomy of innovativeness. Journal of Engineering and Technology Management, Vol. 35, pp. 115-133.

Kirner, E., Kinkel, S., and Jaeger, A. (2009). Innovation paths and the innovation performance of low-technology firms-An empirical analysis of German industry. Research Policy, Vol. 38 No. (3), pp. 447-458. 
Ukko, J., Hildén, S., Saunila, M. and Tikkamäki, K. (2017) Comprehensive performance measurement and management - Innovativeness and performance through reflective practice, Journal of Accounting and Organizational Change, 13 (3): 425-448.

Kolb, D.A. (1984). Experiential Learning: Experience as a Source of Learning and Development. Englewood Cliffs, New Jersey: Prentice-Hall Publisher.

Landry, R., Amara, N., and Lamari, M. (2002). Does social capital determine innovation? To what extent?. Technological Forecasting and Social Change, Vol. 69 No. (7), pp. 681-701.

Laforet, S. (2013). Organizational innovation outcomes in SMEs: Effects of age, size, and sector. Journal of World Business, Vol. 48 No. (4), pp. 490-502.

Laforet, S. (2011). A framework of organisational innovation and outcomes in SMEs. International Journal of Entrepreneurial Behavior \& Research, Vol. 17 No. (4), pp. 380-408.

Lebas, M., and Euske, K. (2002). A conceptual and operational delineation of performance. Business performance measurement: Theory and practice, pp. 65-79.

Lukka, K. (2014). Exploring the possibilities for causal explanation in interpretive research. Accounting, Organizations and Society, Vol. 39 No. (7), pp. 559-566.

Mahama, H. (2006). Management control systems, cooperation and performance in strategic supply relationships: A survey in the mines. Management Accounting Research, Vol. 17 No. (3), pp. 315-339.

Malmi, T., and Brown, D. A. (2008). Management control systems as a package-Opportunities, challenges and research directions. Management Accounting Research, Vol. 19 No. (4), pp. $287-$ 300 .

Martins, E. C., and Terblanche, F. (2003). Building organisational culture that stimulates creativity and innovation. European Journal of Innovation Management, Vol. 6 No. (1), pp. 64-74.

Merchant, K. A., and Otley, D. T. (2006). A review of the literature on control and accountability. Handbooks of management accounting research, Vol. 2, pp. 785-802.

Mezirow, J. (2000). Learning to think like an adult. Learning as transformation: Critical perspectives on a theory in progress, pp. 3-33.

Miner, A. S., and Mezias, S. J. (1996). Ugly duckling no more: Pasts and futures of organizational learning research. Organization Science, Vol. 7 No. (1), pp. 88-99. 
Ukko, J., Hildén, S., Saunila, M. and Tikkamäki, K. (2017) Comprehensive performance measurement and management - Innovativeness and performance through reflective practice, Journal of Accounting and Organizational Change, 13 (3): 425-448.

Mone, M. A., McKinley, W., and Barker, V. L. (1998). Organizational decline and innovation: A contingency framework. Academy of Management Review, Vol. 23 No. (1), pp. 115-132.

Muller, A., Välikangas, L., and Merlyn, P. (2005). Metrics for innovation: guidelines for developing a customized suite of innovation metrics. Strategy \& Leadership, Vol. 33 No. (1), pp. $37-45$.

Nesbit, P. L. (2012). The role of self-reflection, emotional management of feedback, and selfregulation processes in self-directed leadership development. Human Resource Development Review, Vol. 11 No. (2): pp. 203-226.

Nicolini, D., Hartley, J., Stansfield, A., and Hurcombe, J. (2011). Through the eyes of others: Using developmental peer reviews to promote reflection and change in organizations. Journal of Organizational Change Management, Vol. 24 No. (2), pp. 211-228.

Nonaka, I., Toyama, R., and Konno, N. (2000). SECI, Ba and leadership: a unified model of dynamic knowledge creation. Long Range Planning, Vol. 33 No. (1), pp. 5-34.

Ollila, S. (2000). Creativity and innovativeness through reflective project leadership. Creativity and Innovation Management, Vol. 9 No. (3), pp. 195-200.

Otley, D. (1999). Performance management: a framework for management control systems research. Management Accounting Research, 10 No. (4), pp. 363-382.

Page, S., and Meerabeau, L. (2000). Achieving change through reflective practice: closing the loop. Nurse Education Today, Vol. 20 No. (5), pp. 365-372.

Pedler, M., Burgoyne, J. and Boydell, T. (1997). The Learning Company, a Strategy for Sustainable Development. 2nd Edition. London: MacGraw Hill.

Pitt, M., and Tucker, M. (2008). Performance measurement in facilities management: driving innovation?. Property Management, Vol. 26 No. (4), pp. 241-254.

Raelin, J. A. (2001). Public reflection as the basis of learning. Management Learning, Vol. 32 No. (1), pp. 11-30. 
Ukko, J., Hildén, S., Saunila, M. and Tikkamäki, K. (2017) Comprehensive performance measurement and management - Innovativeness and performance through reflective practice, Journal of Accounting and Organizational Change, 13 (3): 425-448.

Roffe, I. (1999). Innovation and creativity in organisations: a review of the implications for training and development. Journal of European industrial training, Vol. 23 No. (4/5), pp. 224241.

Saunila, M., Tikkamäki, K., and Ukko, J. (2015). Managing performance and learning through reflective practices. Journal of Organizational Effectiveness: People and Performance, Vol. 2 No. (4), pp. 370-390.

Saunila, M., and Ukko, J. (2013). Facilitating innovation capability through performance measurement: A study of Finnish SMEs. Management Research Review, Vol. 36 No. (10), pp. 991-1010.

Saunila, M., and Ukko, J. (2015). Reflective practice as a determinant of performance outcomes in services. International Journal of Quality and Service Sciences, Vol. 7 No. (4), pp. 392-403.

Schatzki, T.R. (2002). The Site of the Social: a Philosophical Account of the Constitution of the Social Life and Change. Pennsylvania: Pennsylvania State University Press.

Schön, D.A. (1983). The Reflective Practitioner: How Professionals Think in Action. New York: Basic Books.

Senge, P.M. (1990). The Fifth Discipline: the Art and Practice of the Learning Organization. New York: Doubleday Currency.

Simon, H. A. (1991). Bounded rationality and organizational learning. Organization Science, Vol. 2 No. (1), pp. 125-134.

Simons, R. (2000). Performance Measurement and Control Systems for Implementing Strategies. Upper Saddle River: Prentice Hall.

Smith, M., Busi, M., Ball, P., and Van Der Meer, R. (2008). Factors influencing an organisation's ability to manage innovation: a structured literature review and conceptual model. International Journal of Innovation Management, Vol. 12 No. (04), pp. 655-676.

Smith, T. L., Barlow, P. B., Peters, J. M., and Skolits, G. J. (2015). Demystifying reflective practice: Using the DATA model to enhance evaluators' professional activities. Evaluation and Program Planning, Vol. 52, pp. 142-147. 
Ukko, J., Hildén, S., Saunila, M. and Tikkamäki, K. (2017) Comprehensive performance measurement and management - Innovativeness and performance through reflective practice, Journal of Accounting and Organizational Change, 13 (3): 425-448.

Somech, A. (2006). The effects of leadership style and team process on performance and innovation in functionally heterogeneous teams. Journal of Management, Vol. 32 No. (1), pp. 132157.

Suomala, P., Lyly-Yrjänäinen, J., and Lukka, K. (2014). Battlefield around interventions: A reflective analysis of conducting interventionist research in management accounting. Management Accounting Research, Vol. 25 No. (4), pp. 304-314.

Tidd, J., Bessant, J. and Pavitt, K. (2005). Managing Innovation: Integrating Technological, Market and Organizational Change. West Sussex, England: John Wiley \& Sons.

Tien-Shang Lee, L. (2008). The effects of team reflexivity and innovativeness on new product development performance. Industrial Management \& Data Systems, Vol. 108 No. (4), pp. 548569 .

Tikkamäki K (2006) Learning in Changing Work and Organizational Contexts - Ethnographical Discovery on Workplace Learning. Doctoral dissertation. Tampere: University of Tampere.

Tuomela, T. S. (2005). The interplay of different levers of control: A case study of introducing a new performance measurement system. Management Accounting Research, Vol. 16 No. (3), pp. 293-320.

Tushman, M. L., and O'Reilly, C. A. (1996). The ambidextrous organizations: Managing evolutionary and revolutionary change. California Management Review, Vol. 38 No. (4), pp. 8-30.

Ulrich, D. (2013). Human resource champions: The next agenda for adding value and delivering results. Harvard Business Press.

Vince, R. (2002). Organizing reflection. Management learning, Vol. 33 No. (1), pp. 63-78.

Weehuisen, R. (2008). Mental Capital. The Economic Significance of Mental Health. Maastricht: Universitaire Pers Maastricht.

Wiersma, E. (2009). For which purposes do managers use Balanced Scorecards?: An empirical study. Management Accounting Research, Vol. 20 No. (4), pp. 239-251. 
Ukko, J., Hildén, S., Saunila, M. and Tikkamäki, K. (2017) Comprehensive performance measurement and management - Innovativeness and performance through reflective practice, Journal of Accounting and Organizational Change, 13 (3): 425-448.

Van Woerkom, M. (2004). The concept of critical reflection and its implications for human resource development. Advances in Developing Human Resources, Vol. 6 No. (2), pp. 178-192.

Wouters, M., and Wilderom, C. (2008). Developing performance-measurement systems as enabling formalization: A longitudinal field study of a logistics department. Accounting, Organizations and Society, Vol. 33 No. (4), pp. 488-516.

Yang, C. C., Marlow, P. B., and Lu, C. S. (2009). Assessing resources, logistics service capabilities, innovation capabilities and the performance of container shipping services in Taiwan. International Journal of Production Economics, Vol. 122 No. (1), pp. 4-20.

Yang, B., Watkins, K. E., and Marsick, V. J. (2004). The construct of the learning organization: Dimensions, measurement, and validation. Human Resource Development Quarterly, Vol. 15 No. (1), pp. 31-55. 
Saunila, M., Rantala, T., Ukko, J. \& Pekkola, S. (2017). Gaining insights into the measurement of value in industrial service network. International Journal of Quality \& Reliability Management, 34(4), 478-493.

\section{APPENDIX}

\section{Reflective practice at the individual level}

1. I think it is valuable to take time to think critically and creatively about my work.

2. In order to achieve my work objectives, I regularly have to think critically and creatively about my work.

3. I use financial and non-financial performance metrics in my work when I search for explanations and/or new ideas.

4. I regularly take time to think critically and creatively about my work because my organization rewards me for it.

5. I regularly review and evaluate my work and the ways in which I work.

\section{Reflective practice at the group level}

1. In our organization, it is considered valuable to regularly take time for critical and creative discussion and thinking.

2. In order to achieve our work objectives, we regularly need to think critically and creatively about our work and working methods.

3. We use financial and non-financial performance metrics when searching for explanations or new ideas along with others (e.g., in teams/working groups).

4. We regularly take time to critically and creatively discuss our work with others because we are rewarded for it.

5. We regularly review and evaluate our work and the ways in which we work along with others.

\section{Reflective practice at the organizational level}

1. Critical and creative thinking individually or collectively is valued in our organization.

2. The strategic goals of our organization encourage sharing thoughts and creative thinking.

3. The performance metrics (financial and/or non-financial) are developed based on new ideas and improvements we have made, e.g., to work processes.

4. The current reward practices of my company rewards us for developing new ideas and improving work practices.

5. Ideas or suggestions for improvement we have given individually or collectively change the processes and the ways we work in my company.

\section{Innovativeness}

1. I'm good at developing new work-related ideas.

2. We develop new ideas together in our work group.

3. The ideas are regularly utilized by the organization. 